\title{
Evaluasi Sistem Informasi Kesehatan di Provinsi Jawa Tengah Dalam Rangka Penguatan Sistem Informasi Kesehatan Nasional
}

\author{
Endah Sri Lestari ${ }^{1}$, Sutopo Patria Jati ${ }^{2}$, Aris Puji Widodo ${ }^{3}$ \\ 1) Dinas Kesehatan Provinsi Jawa Tengah, Jl. Piere Tendean No. 24 Semarang \\ Telp.024-3511351,e-mail : endarifah@gmail.com \\ ${ }^{2}$ Fakultas Kesehatan Masyarakat, Universitas Diponegoro, Semarang \\ ${ }^{3}$ Fakultas Sains dan Matematika, Universitas Diponegoro, Semarang
}

Title : Evaluation of Central Java Provincial Health Information Systems on Strengthening National Health Information System

\begin{abstract}
Abstrak
Evaluasi SIK bertujuan untuk memastikan SIK berjalan secara efisien, mampu mengumpulkan informasi yang relevan dan berkualitas sebagai dasar pengambilan keputusan oleh pemangku kebijakan. Hasil penilaian SIK sangat dibutuhkan dalam meningkatkan kinerja SIK. SIK Provinsi Jawa Tengah merupakan sub sistem dari SIKNAS sehingga pengembangan SIK Provinsi Jawa Tengah akan berpengaruh terhadap penguatan SIKNAS. Tujuan dari penelitian ini adalah untuk mengevaluasi SIK di Provinsi Jawa Tengah dalam rangka Penguatan SIKNAS.

Penelitian ini merupakan penelitan deskriptif evaluatif dengan pendekatan kuantitatif dan kualitatif. Subyek penelitian adalah 35 petugas SIK DKK dan enam petugas SIK Dinas Kesehatan Provinsi Jawa Tengah. Pengumpulan data kuantitatif melalui pengisian kuesioner, pengumpulan data kualitatif melalui FGD dan wawancara. Analisis data penelitian dilakukan dengan menggunakan perangkat Evaluasi SIK Provinsi yang merupakan modifikasi dari Assessment Tool HMN Versi 4.00.

Modifikasi Assessment Tool HMN Versi 4.00 dilakukan dengan cara menghapus item pertanyaan yang tidak relevan dengan SIK di provinsi dan menambahkan item pertanyaan berdasarkan PP no 46/2016 tentang SIK. Hasil evaluasi terhadap tujuh komponen SIK, empat diantaranya dinilai "ada tapi tidak adekuat" yaitu komponen pengelolaan $(54,7 \%)$, sumber daya $(54,2 \%)$, sumber data $(58 \%)$ dan manajemen data $(41,3 \%)$. Sementara tiga komponen lainnya dinilai "adekuat", yaitu komponen indikator $(74,3 \%)$, produk informasi $(71,3 \%)$ dan diseminasi dan penggunaan informasi (74,5\%). Disimpulkan bahwa secara umum SIK Provinsi Jawa Tengah
\end{abstract}

berada dalam kategori "adekuat". Untuk meningkatkan pengelolaan SIK di Provinsi Jawa Tengah, direkomendasikan untuk membuat suatu standar tata kelola SIK sebagai acuan pengelolaan SIK di Provinsi Jawa Tengah.

Kata kunci : Evaluasi, komponen SIK, Provinsi, HMN

Kepustakaan : $14(2005-2014)$

\section{Abstract}

Evaluation of Health Information System (HIS) aims to ensure the HIS run efficiently, able to collect relevant information and qualified as a basis for decision making by policy makers. Results ratings HIS is needed to improve the performance of the HIS. Central Java provincial HIS is a sub-system of the National Health Information System so that the development of Central Java provincial HIS will affect the strengthening of the National Health Information System. The purpose of this study was to evaluate the Central Java provincial HIS on strengthening the National Health Information System.

This study is an evaluative descriptive research with quantitative and qualitative approaches. Subjects were 35 HIS officers of District Health Offices and six officers HIS Central Java Provincial Health Office. The collection of quantitative data through questionnaires, qualitative data collection through focus group discussions and interviews. Research data analysis done by using the Provincial HIS evaluation tools which is a modification of the HMN Assessment Tool Version 4:00.

Modification HMN Assessment Tool Version 4:00 is done by deleting the irrelevant question to Provincial HIS and add questions based on PP No.. 46/2016 about HIS. The results of an evaluation of the seven HIS components, four of which were rated "present but inadequate" ie component management (54.7\%), resources 
(54.2\%), the source of the data (58\%) and data management (41.3\%). While the three other components rated "adequate", ie the component indicators $(74.3 \%)$, product information $(71.3 \%)$ and the dissemination and use of information (74.5\%). Concluded that in general the Central Java Provincial HIS is in the category "adequate". To improve the management of the Central Java Provincial HIS, it is recommended to create a governance standards of HIS as a reference for the HIS management in Central Java Province.

Keywords: Evaluation, HIS component, Province, $H M N$

Bibliography: 14 (2005-2014)

\section{Pendahuluan}

Pengambilan keputusan di bidang kesehatan menjadi lebih mudah jika semua informasi yang dibutuhkan sudah tersedia, untuk tujuan itu suatu sistem informasi kesehatan perlu dibangun. ${ }^{1}$ Sistem Informasi Kesehatan (SIK) adalah seperangkat tatanan yang meliputi data, informasi, indikator, prosedur, perangkat, teknologi, dan sumber daya manusia yang saling berkaitan dan dikelola secara terpadu yang menyediakan dukungan informasi bagi proses pengambilan keputusan, perencanaan program kesehatan, monitoring pelaksanaan dan evaluasi ${ }^{2} \mathrm{di}$ setiap jenjang administrasi kesehatan. ${ }^{1-3}$

Dasar hukum pelaksanaan SIK di Indonesia adalah PP Nomor 46 tahun 2014 tentang SIK. Penyelengaraan SIK mencakup (i) pelaksanaan SIK, yang meliputi data kesehatan, informasi kesehatan, indikator kesehatan, sumber data dan informasi, pengumpulan data dan informasi, pengolahan data dan informasi, penyimpanan data dan informasi, keamanan dan kerahasiaan informasi; (ii) pengelolaan SIK; (iii) sumber daya SIK; (iv) pengembangan SIK; dan (v) penyebarluasan dan penggunaan Data dan Informasi Kesehatan. ${ }^{3}$

Penguatan SIK di Indonesia dilakukan dengan mengembangkan model SIK nasional yaitu SIK yang terintegrasi, yang menyediakan mekanisme saling hubung antar sub sistem informasi dengan berbagai cara yang sesuai. ${ }^{4}$ SIKNAS dibangun dari himpunan atau jaringan SIK Provinsi dan SIK Provinsi dibangun dari himpunan atau jaringan SIK Kabupaten/Kota. ${ }^{5}$
Pengelolaan SIK di tingkat provinsi berdasarkan PP Nomor 38 Tahun 2007 yang menjelaskan bahwa pemerintah daerah provinsi bertanggung jawab dalam pengelolaan SIK skala provinsi ${ }^{6}$ dan PP Nomor 46 tahun 2014 pasal 34 yang menyebutkan bahwa SIK provinsi dikelola oleh unit kerja struktural atau fungsional pada satuan kerja perangkat daerah provinsi yang menyelenggarakan urusan pemerintahan di bidang kesehatan. ${ }^{3}$

Pengelolaan SIK di Provinsi Jawa Tengah dilaksanakan oleh Seksi Manajemen Informasi dan Pengembangan Kesehatan Dinas Kesehatan Provinsi Jawa Tengah. Provinsi Jawa Tengah terdiri dari 29 kabupaten dan 6 kota, mempunyai 75 RS pemerintah, 203 RS Swasta dan 875 puskesmas.

SIK bertujuan untuk mengatasi terfragmentasinya data kesehatan, mengurangi redudansi dan inkonsistensi, mempercepat proses pengolahan data, serta memperbaiki mekanisme pelaporan, kelengkapan dan integrasi data pada tingkat administrasi yang lebih tinggi, namun beberapa pengalaman menunjukkan masih lemahnya proses-proses tersebut sehingga data kesehatan belum dapat dipercaya untuk digunakan dalam pengambilan keputusan. ${ }^{7}$ Meskipun data yang dikumpulkan sudah lebih baik, permasalahan lain adalah kemampuan dalam menganalisis dan mengelola data masih lemah serta kurangnya pemanfaatan data dan informasi untuk pengambilan keputusan. ${ }^{8}$ Penelitian di Tanzania menunjukkan bahwa lemahnya pengumpulan data kesehatan dan kurangnya informasi pengambilan keputusan di fasilitas pelayanan kesehatan menjadi faktor sulitnya pengembangan SIK. ${ }^{2}$

Hasil penilaian terhadap SIK Indonesia yang dilaksanakan oleh Pusat Data dan Informasi Kementerian Kesehatan Republik Indonesia pada tahun 2007 dengan menggunakan Health Metrics Network (HMN) Framework secara umum menunjukkan bahwa semua komponen "ada tapi tidak adekuat" (51\%). Dari enam komponen dan standar SIK, lima diantaranya dinilai "ada tapi tidak adekuat" yaitu sumber daya (47\%), indikator $(61 \%)$, sumber data $(51 \%)$, kualitas data $(55 \%)$, dan diseminasi dan penggunaan 
informasi (57\%). Sementara ada satu komponen yang dinilai "tidak adekuat sama sekali", yaitu komponen manajemen data $(35 \%) .{ }^{9}$

Penelitian yang dilakukan oleh Utami, et al., (2013) tentang Evaluasi Kinerja Sistem Informasi Kesehatan di Propinsi Bangka Belitung di peroleh hasil bahwa secara teknis dan organisasi masih lemah, kompleksitas pelaporan dan prosedur pengisian rendah, pengumpulan dan pelaporan terfragmentasi dan tumpang tindih. ${ }^{10}$ Budi et al., (2010) dalam penelitiannya tentang Analisis Sumber Daya Sistem Informasi Kesehatan Kabupaten Ketapang dengan Pendekatan HMN diperoleh hasil pada umumnya adalah "ada tetapi tidak adekuat", tetapi infrastrukturnya yang "adekuat". ${ }^{11}$

Evaluasi SIK bertujuan untuk memastikan bahwa SIK berjalan secara efisien, mampu mengumpulkan informasi yang relevan dan berkualitas sebagai dasar pengambilan keputusan oleh pemangku kebijakan. $^{12}$ Hasil penilaian SIK sangat dibutuhkan dalam meningkatkan kinerja SIK secara terus-menerus. ${ }^{8}$ Untuk mengevaluasi SIK dalam rangka memperkuat SIK di tingkat nasional, maka dibentuklah HMN pada tahun 2005 yang merupakan hasil kesepakatan global. HMN telah mengembangkan referensi standar untuk pengembangan SIK yang selanjutnya disebut HMN Framework. Komponen dan standar yang mempengaruhi kinerja dari SIK diantaranya adalah sumber daya SIK, indikator, sumber data, manajemen data, produk informasi, diseminasi dan penggunaan data. ${ }^{13}$

SIK Provinsi Jawa Tengah merupakan sub sistem dari SIKNAS sehingga pengembangan SIK Provinsi Jawa Tengah akan berpengaruh terhadap penguatan SIKNAS. Saat ini belum ada dokumen roadmap pengembangan SIK Provinsi Jawa Tengah. Untuk menyusun roadmap maka diperlukan informasi mengenai situasi SIK di Provinsi Jawa Tengah saat ini. Sehingga penelitin ini bertujuan untuk mengevaluasi Sistem Informasi Kesehatan di Provinsi Jawa Tengah dalam rangka Penguatan Sistem Informasi Kesehatan Nasional.

\section{Metode Penelitian}

Jenis penelitian ini adalah deskriptif evaluatif dengan sequential explanatory design. Objek penelitian adalah SIK di Provinsi Jawa Tengah yang difokuskan pada pelaksanaan penyelenggaraan SIK di DKK (DKK) dan Dinas Kesehatan Provinsi Jawa Tengah. Subjek penelitiannya adalah petugas SIK di 35 DKK, enam orang pengelola SIK Dinas Kesehatan Provinsi Jawa Tengah dan Kepala Seksi Manajemen Informasi dan Pengembangan Kesehatan. Cara pengumpulan datanya adalah dengan pengisian kuesioner, wawancara, FGD dan telaah dokumen. Analisa data kuantitatif pada penelitian ini menggunakan Assessment Tool HMN Versi 4.00 yang telah dimodifikasi. Analisa data kualitatif digunakan sebagai bahan untuk melengkapi analisa kuantitatif.

\section{Hasil}

Karakteristik Responden

Responden dalam penelitian ini sebanyak 41 orang dengan rincian 35 orang petugas SIK DKK dan 6 orang petugas SIK Dinas Kesehatan Provinsi Jawa Tengah. Karakteristik responden penelitian ini secara lengkap dapat dilihat pada Tabel 1.

Tabel 1. Distribusi Frekuensi Karakteristik Responden

\begin{tabular}{|c|c|c|c|}
\hline No & Karakteristik & Jumlah & $\%$ \\
\hline \multirow[t]{3}{*}{1} & Jenis Kelamin & & \\
\hline & - Laki-laki & 22 & 53,7 \\
\hline & - Perempuan & 19 & 46,3 \\
\hline \multirow[t]{5}{*}{2} & Tingkat Pendidikan & & \\
\hline & - $\quad$ S2 & 20 & 48,8 \\
\hline & $-\mathrm{S} 1$ & 16 & 39,0 \\
\hline & - D4 & 1 & 2,4 \\
\hline & - D3 & 4 & 9,8 \\
\hline \multirow[t]{2}{*}{3} & Jenis Pendidikan & & \\
\hline & - Komputer & 6 & 14,6 \\
\hline
\end{tabular}




\begin{tabular}{|c|c|c|c|}
\hline & - Kesehatan Masyarakat & 20 & 48,8 \\
\hline & - Manajemen & 6 & 14,6 \\
\hline & - Lainnya & 9 & 22,0 \\
\hline \multirow[t]{3}{*}{4} & Jabatan & & \\
\hline & - Kepala Seksi & 14 & 34,1 \\
\hline & - $\quad$ staff & 27 & 65,9 \\
\hline \multirow[t]{4}{*}{5} & Lama menjadi petugas SIK & & \\
\hline & $-\quad<5$ tahun & 17 & 41,5 \\
\hline & - $\quad 5-10$ tahun & 13 & 31,7 \\
\hline & $-\quad>10$ tahun & 11 & 26,8 \\
\hline
\end{tabular}

Modifikasi Assessment Tool HMN Versi 4.00 Menjadi Perangkat Evaluasi SIK Provinsi

Assessment Tool HMN Versi 4.00 yang dikembangkan oleh HMN digunakan untuk mengevaluasi SIK di tingkat nasional, sementara pada penelitian ini bertujuan untuk melakukan evaluasi SIK di tingkat provinsi, sehingga diperlukan modifikasi instrumen. Modifikasi dilakukan pada item pertanyaan dengan cara menghapus item pertanyaan yang tidak sesuai dengan kondisi SIK di provinsi dan menambahkan item pertanyaan berdasarkan pada PP no 46 Tahun 2014 tentang SIK. Kriteria yang digunakan sebagai dasar dalam menghapus beberapa item pertanyaan adalah sebagai berikut :

a, Jika pertanyaan tersebut ditujukan untuk penilaian terhadap Biro Pusat Statistik.

b, Jika pertanyaan tersebut kurang relevan karena merupakan kewenangan pemerintah pusat.

Instrumen evaluasi SIK provinsi yang sudah disusun diuji validitas dan reliabilitas dan diperoleh jumlah pertanyaan sebanyak 98 item pertanyaan yang dapat dilihat pada Tabel 2.

Tabel 2. Modifikasi jumlah pertanyaan dalam Assessment Tool $\mathrm{HMN}^{14}$ menjadi kuesioner dalam Evaluasi SIK Provinsi

\begin{tabular}{rlcc}
\hline \multicolumn{1}{c}{ Kategori } & $\begin{array}{c}\text { Jumlah pertanyaan } \\
\text { dalam Assessment } \\
\text { Tool HMN }\end{array}$ & $\begin{array}{c}\text { Jumlah pertanyaan } \\
\text { dalam Kuesioner } \\
\text { Evaluasi SIK Provinsi }\end{array}$ \\
\hline I, $\quad$ Pengelolaan & 0 & 5 \\
II, $\quad$ Sumber Daya & 7 & 0 \\
& A, Kebijakan dan perencanaan & 13 & 6 \\
& B, Institusi, SDM \& Anggaran & 5 & 6 \\
C, Infrastruktur & 5 & 5 \\
III, & Indikator & & 0 \\
IV, Sumber Data & 10 & 0 \\
& A, Sensus & 13 & 5 \\
& B, Statistik vital & 11 & 4 \\
C, Survei penduduk & 13 & 6 \\
D, Catatan kesehatan dan penyakit & 11 & 9 \\
E, Catatan Pelayanan Kesehatan & 25 & 4 \\
F, Catatan Sumber Daya & & 38 \\
V, Manajemen Data & 5 & 10 \\
VI, Produk Informasi & 69 & 98 \\
VII, Diseminasi dan Penggunaan & 10 & \\
\hline
\end{tabular}

Langkah selanjutnya setelah memperoleh item pertanyaan yang valid dan reliabel adalah melakukan modifikasi HMN Assessment Tool version 4.00 menjadi perangkat evaluasi SIK Provinsi dalam bentuk spreadsheet Microsoft Excel.

Evaluasi SIK di Provinsi Jawa Tengah 
Evaluasi SIK di Provinsi Jawa Tengah dilakukan terhadap 7 komponen SIK, yaitu pengelolaan SIK, Sumber Daya SIK, Indikator SIK, Sumber Data SIK, Manajemen Data SIK, Produk Informasi dan Diseminasi dan Penggunaan Informasi. Hasil evaluasi 7 komponen SIK di Provinsi Jawa Tengah dapat dilihat pada Tabel 3.

Tabel 3. Hasil Evaluasi 7 Komponen SIK di Provinsi Jawa Tengah Tahun 2016

\begin{tabular}{|c|c|c|c|c|c|}
\hline No & Kategori & $\begin{array}{l}\text { Total Skor } \\
\text { Maksimum }\end{array}$ & $\begin{array}{c}\text { Skor } \\
\text { Rata- } \\
\text { rata }\end{array}$ & $\%$ & Kategori \\
\hline 1 & Pengelolaan SIK & 15 & 8,2 & 54,7 & Ada tapi tidak adekuat \\
\hline 2 & Sumber Daya SIK & 36 & 19,5 & 54,2 & Ada tapi tidak adekuat \\
\hline & - $\quad$ SDM \& Pendanaan & 18 & 7,2 & 40,1 & Ada tapi tidak adekuat \\
\hline & - Infrastruktur & 18 & 12,3 & 68,3 & Adekuat \\
\hline 3 & Indikator SIK & 15 & 11,1 & 74,3 & Adekuat \\
\hline 4 & Sumber Data SIK & 72 & 41,7 & 58,0 & Ada tapi tidak adekuat \\
\hline 5 & Manajemen Data SIK & 12 & 5,0 & 41,3 & Ada tapi tidak adekuat \\
\hline 6 & Produk Informasi & 114 & 81,2 & 71,3 & Adekuat \\
\hline & $\begin{array}{l}\text { - Indikator Status } \\
\text { Kesehatan }\end{array}$ & 54 & 43,4 & 80,4 & Sangat adekuat \\
\hline \multirow{5}{*}{7} & $\begin{array}{l}\text { - Indikator Sistem } \\
\text { Kesehatan }\end{array}$ & 42 & 31,5 & 75,0 & Adekuat \\
\hline & - $\quad$ Indikator Faktor Risiko & 18 & 6,3 & 35,1 & Tidak Adekuat sama sekali \\
\hline & $\begin{array}{l}\text { Diseminasi dan Penggunaan } \\
\text { Informasi }\end{array}$ & 30 & 22,4 & 74,5 & Adekuat \\
\hline & - Diseminasi Informasi & 9 & 7,2 & 79,5 & Adekuat \\
\hline & - $\quad$ Penggunaan Informasi & 21 & 15,2 & 72,4 & Adekuat \\
\hline
\end{tabular}

\section{Pembahasan}

Sebagian besar komponen SIK Provinsi Jawa Tengah berada dalam kategori "Ada tapi tidak adekuat" yaitu komponen Pengelolaan, Sumber Daya, Sumber Data dan Manajemen Data. Tiga komponen lainnya yaitu komponen indikator, komponen produk informasi dan komponen diseminasi dan penggunaan informasi berada dalam kategori "Adekuat". Hasil secara keseluruhan evaluasi 7 komponen SIK di Provinsi Jawa Tengah adalah berada dalam kategori "Adekuat". Hasil evaluasi masing-masing komponen SIK di Provinsi Jawa Tengah adalah sebagai berikut :

Evaluasi Pengelolaan SIK di Provinsi Jawa Tengah

Evaluasi pengelolaan SIK di Provinsi Jawa Tengah dilakukan dengan memberikan penilaian terhadap keberadaan peraturan dan prosedur SIK, dokumen renstra SIK, sistem rutin pemantauan kinerja SIK, kebijakan pertemuan rutin SIK dan unit kerja struktural atau fungsional SIK di DKK dan di Dinas Kesehatan Provinsi Jawa Tengah. Pengelolaan SIK di Provinsi Jawa Tengah termasuk dalam kategori "ada tapi tidak adekuat" (54,7\%).

Tidak ada kebijakan khusus yang mengatur pengelolaan SIK baik dalam bentuk peraturan maupun prosedur di tingkat kabupaten/kota dan provinsi. Hal ini seperti yang disampaikan oleh Kepala Seksi Manajemen Informasi dan Pengembangan Kesehatan (Mibangkes) Dinas Kesehatan Provinsi Jawa Tengah berikut ini.

“...kebijakan SIK di Provinsi Jawa Tengah...kalau khusus untuk Jawa Tengah nggak ada, tapi kebijakan secara nasional pasti ya..."

Pelaksanaan pengelolaan SIK di Provinsi Jawa Tengah mengacu pada PP no 46 Tahun 2014. PP tentang SIK tersebut telah mengatur kerangka kerja untuk SIK, yang meliputi pengumpulan, pengolahan dan penggunaan data kesehatan, perencanaan pembangunan dan pengembangan infrastruktur SIK dan komponen SIK lainnya. Implementasi PP tentang SIK di Provinsi Jawa 
Tengah belum optimal, hal ini bisa dilihat pada kondisi SDM dan anggaran SIK yang belum memadai di tingkat kabupaten/kota.

Berdasarkan hasil FGD diperoleh informasi bahwa saat ini baik di provinsi dan kabupaten tidak ada peraturan khusus tentang SIK, yang ada peraturan tentang Keterbukaan Informasi Publik. Mereka mengharapkan ada Peraturan Daerah tentang SIK di tingkat provinsi yang menjadi acuan maupun dasar untuk membuat peraturan SIK di tingkat kabupaten/kota. Dalam pedoman SIK disampaikan bahwa pelaksanaan SIK di tingkat provinsi/kabupaten/kota juga harus didukung oleh suatu kebijakan yang memperkuatnya sebagai pijakan pelaksanaan bagi pengelola SIK di daerah, dengan membuat peraturan daerah mengenai SIK yang sejalan dengan SIK Nasional. ${ }^{1}$

Dokumen renstra SIK belum tersedia secara khusus di Provinsi Jawa Tengah, baru menjadi bagian dari renstra di Dinas Kesehatan tapi sudah ada upaya untuk integrasi sumber data yang berbeda. Salah satu upaya integrasi sumber data yang berbeda adalah LIKES Jateng yang merupakan dashboard layanan informasi kesehatan yang memuat 12 program nasional dan daerah. Melalui sistem ini pengelola program kesehatan bisa menginputkan datanya kemudian hasilnya bisa dilihat dan dimanfaatkan oleh lintas program, lintas sektor, institusi pendidikan, pengambil kebijakan dan masyarakat.

Sistem rutin untuk memantau kinerja SIK dan subsistemnya di Provinsi Jawa Tengah telah tersedia tetapi jarang digunakan. Kebijakan pertemuan rutin sudah ada, tetapi implementasinya tidak sesuai karena pertemuan tidak dilaksanakan secara rutin hanya berdasarkan kebutuhan pada saat itu. Hasil monev SIK kadang tidak ditindaklanjuti maupun jarang digunakan untuk merencanakan kegiatan selanjutnya.

Evaluasi Sumber Daya SIK di Provinsi Jawa Tengah

Keberhasilan pelaksanaan suatu sistem bergantung pada sumber daya yang mendukung sistem tersebut. Sumber daya SIK di Provinsi Jawa Tengah termasuk dalam kategori "ada tapi tidak adekuat" $(54,2 \%)$.

Kualitas sumber daya manusia SIK di Provinsi Jateng belum optimal. Hal ini disebabkan rendahnya apresiasi akan pentingnya informasi sehingga sumber daya manusia yang ditugaskan untuk SIK belum mempunyai kapasitas yang memadai. Berdasarkan PP 46 tentang SIK pasal 51 ayat (2) disebutkan bahwa sumber daya manusia yang mengelola SIK harus memiliki kompetensi paling sedikit di bidang statistik, komputer dan epidemiologi. Petugas SIK di Provinsi Jawa Tengah yang mempunyai latar belakang pendidikan komputer dan kesehatan masyarakat sebesar $63,4 \%$. Untuk memenuhi kekurangan kompetensi tersebut perlu dilakukan pelatihan peningkatan kapasitas petugas secara berkala. Upaya untuk meningkatkan kapasitas petugas SIK baik di tingkat kabupaten/kota maupun di provinsi juga belum terencana dengan baik.

Kuantitas sumber daya manusia SIK juga belum optimal, masih ada kabupaten/kota yang petugasnya sangat kurang bahkan beberapa dari mereka juga melaksanakan tugas sebagai pengelola program kesehatan lainnya. Kurangnya petugas SIK yang fulltime dan tingkat mutasi yang cepat juga menambah masalah yang ada.

Anggaran yang tersedia untuk SIK dinilai belum memadai, meskipun ada peningkatan tapi belum signifikan. Adanya peraturan penggunaan anggaran APBD yang kurang mendukung untuk pengembangan SIK di beberapa kabupaten/kota sehingga belum bisa memenuhi kebutuhan pengembangan SIK di daerah. Proporsi terbesar anggaran adalah untuk memenuhi kebutuhan infrastruktur SIK, namun peningkatan tersebut tidak diiringi dengan peningkatan kuantitas dan kualitas SDM pengelola SIK.

Infrastruktur menjadi penunjang dalam pengelolaan SIK di Provinsi Jawa Tengah. Hasil penilaian terhadap sub komponen infrastruktur ini masuk dalam kategori "adekuat" (68,3\%). Perangkat keras elektronik dan non elektronik tersedia di hampir semua DKK dan Dinas Kesehatan Provinsi, bahkan di sebagian besar puskesmas sudah tersedia. Perangkat lunak yang mampu menerima, mengirimkan, memproses dan mempublikasikan dokumen elektronik sudah memadai di semua DKK. Perangkat keras dan perangkat lunak yang ada belum semuanya mudah 
beradaptasi dengan SIKNAS dan mampu menyimpan data maupun membuat cadangan data secara otomatis dan terpisah. Ketersediaan dukungan berupa anggaran untuk pemeliharaan perangkat lunak dan keras di Dinas Kesehatan Provinsi dan DKK di Jawa Tengah dinilai telah memadai.

Evaluasi Indikator SIK di Provinsi Jawa Tengah

Hasil penilaian terhadap indikator SIK adalah masuk dalam kategori "adekuat" (74,3\%). Artinya bahwa pemilihan dan penetapan indikator SIK di Provinsi Jawa Tengah sudah sesuai dengan ketentuan dalam PP nomor 46 tahun 2014 dan kerangka HMN.

Indikator inti minimal di tingkat provinsi dan kabupaten/kota sudah mencakup semua kategori dalam indikator kesehatan, dipilih berdasarkan kegunaan, ilmiah, reliabilitas, representatif, kelayakan dan aksesibilitas. Indikator kesehatan di tingkat provinsi dan kabupaten/kota ditetapkan oleh kepala daerah dan mengacu pada indikator di atasnya. Pemilihan indikator dilakukan bersama-sama dengan lintas program dan selanjutnya didiskusikan dengan lintas sektor terkait yaitu Bappeda, BPS, BKKBN, Organisasi Profesi.

Evaluasi Sumber Data SIK di Provinsi Jawa Tengah

Data dan Informasi Kesehatan dalam penyelenggaraan SIK bersumber dari fasilitas kesehatan, termasuk fasilitas pelayanan kesehatan milik Pemerintah, Pemerintah Daerah, dan swasta; dan masyarakat, baik perorangan maupun kelompok. ${ }^{3}$ Berdasarkan hasil evaluasi diketahui bahwa komponen sumber data SIK di Provinsi Jawa Tengah masuk dalam kategori "ada tapi tidak adekuat" (58,0\%).

Sumber data SIK di Provinsi Jawa Tengah diperoleh dari hasil survei, pencatatan kesehatan dan penyakit, pencatatan pelayanan kesehatan, dan pencatatan administrasi. Survei nasional yang diselenggarakan dalam lima tahun terakhir adalah Riset Kesehatan Dasar (Riskesdas), Riset Fasilitas Kesehatan dan Survei Diet Total. Berdasarkan hasil evaluasi diketahui bahwa data yang diperoleh dari hasil survei belum menjadi sumber data yang memadai untuk kebutuhan SIK di Provinsi Jawa Tengah. Pemilahan data berdasarkan status ekonomi dan pendidikan belum tersedia secara memadai.

Sumber data pencatatan kesehatan dan penyakit secara umum sudah memadai, tetapi masih ada beberapa hal yang tidak memadai diantaranya tentang pemetaan populasi berisiko dan penyebarluasan serta umpan balik data surveilans tentang penyakit rawan epidemi. Data yang bersumber dari fasilitas layanan kesehatan umum dan swasta belum semua berbasis sistem informasi sehingga belum bisa disatukan dan belum ada mekanisme untuk memverifikasi kelengkapan dan konsistensi datanya.

Sumber data yang berasal dari pencatatan administrasi terdiri dari database SDM, data persediaan, peralatan dan infrastruktur, data pasokan dan komoditas (obat-obatan, vaksin dan alat kontrasepsi) dan SDM pengelola data tersebut. Secara umum hasil evaluasi sumber data yang berasal dari pencatatan administrasi adalah memadai, dimana update database SDM telah dilakukan setiap tahun, laporan data persediaan, peralatan, infrastruktur, pasokan dan komoditas ke sektor publik setidaknya setiap tahun sekali.

Evaluasi Manajemen Data SIK di Provinsi Jawa Tengah

Secara keseluruhan hasil evaluasi manajemen data SIK di Provinsi Jawa Tengah masuk dalam kategori "ada tapi tidak adekuat" $(41,3 \%)$. Prosedur tertulis untuk pengelolaan data yang meliputi pengumpulan data, penyimpanan, cleaning, quality control, analisis dan penyajian belum tersedia dalam bentuk SPO di tk provinsi dan kabupaten/kota, sebagai mana yang disampaikan oleh Kepala Seksi Mibangkes berikut ini :

"...kalo kita di sini secara tertulis tidak ada....kita tidak mengotak-atik manajemen data yang di kabupaten/kota, karena masing-masing kabupaten beda-beda, hanya untuk 115 variabel yang dari pusat yang kita atur proses pengumpulan datanya...."

Berdasarkan hasil FGD diperoleh informasi bahwa tidak adanya kesamaan prosedur pengumpulan data di provinsi dan kabupaten/kota sehingga data sering berbeda antara data di provinsi dan di kabupaten. Provinsi menerapkan cut of point pengumpulan data di setiap tanggal 
10 pada bulan berikutnya, sementara pada tanggal tersebut belum semua laporan dari puskesmas masuk ke DKK, sehingga data yang masuk ke provinsi belum data terakhir dan data yang masuk setelah tanggal tersebut dianggap tidak ada.

Di tingkat provinsi sudah tersedia bank data tetapi pemanfaatannya belum optimal, sosialisasi dan upaya untuk meningkatkan pemanfaatan terus dilakukan oleh pengelola SIK di Provinsi Jawa Tengah.

Evaluasi Produk Informasi SIK di Provinsi Jawa Tengah

Hasil evaluasi terhadap produk informasi SIK di Provinsi Jawa Tengah secara umum adalah "adekuat" (71,3\%). Evaluasi dilakukan pada enam indikator yaitu 1) kematian balita, 2) kematian ibu, 3) Prevalensi HIV, 4) Cakupan Vaksinasi Campak, 5) Persalinan oleh tenaga kesehatan dan 6) Prevalensi merokok (>15 tahun). Evaluasi terhadap metode pengumpulan data yang meliputi ketepatan waktu, periodisitas, konsistensi, keterwakilan dan pemilahan, semuanya masuk dalam kategori "adekuat" dengan prosentase skor $62 \%-73 \%$.

Indikator status kesehatan dan indikator sistem kesehatan di Provinsi Jawa Tengah dikumpulkan melalui laporan rutin puskesmas dan rumah sakit yang dilaporkan secara berjenjang ke Dinas Kesehatan Provinsi Jawa Tengah. Evaluasi terhadap indikator faktor risiko dilakukan terhadap indikator prevalensi merokok ( $>15$ tahun) dan hasilnya adalah masuk dalam kategori "tidak adekuat sama sekali". Sebagian besar kabupaten/kota tidak mempunyai data rutin maupun hasil survei populasi tentang jumlah perokok. Karakteristik merokok sebagai faktor risiko penting hanya dikumpulkan melalui Riskesdas yang juga menggunakan kuesioner estimasi. Evaluasi Diseminasi dan Penggunaan Informasi di Provinsi Jawa Tengah

Hasil evaluasi terhadap Diseminasi dan Penggunaan Informasi pada SIK di Provinsi Jawa Tengah adalah "adekuat" (74,5\%) artinya bahwa penyebaran dan penggunaan data dan informasi hasil dari SIK di Provinsi Jawa Tengah sudah baik. Dinas Kesehatan telah menyediakan website sebagai sarana untuk menyebarkan informasi ke masyarakat.

Hasil evaluasi terhadap diseminasi informasi pada SIK di Provinsi Jawa Tengah adalah "adekuat" (79,5\%). Kebutuhan akan informasi SIK yang lengkap, tepat waktu, akurat, relevan dan valid sangat tinggi sebagai bahan untuk pengambilan keputusan dengan berdasarkan bukti yang kuat. Hasil analisis SIK disajikan dalam bentuk narasi, grafik dan peta baik di fasilitas kesehatan maupun dinas kesehatan. Penyebaran informasi kesehatan di Dinas Provinsi Jawa Tengah adalah melalui website, seperti yang disampaikan oleh Kepala Seksi Mibangkes berikut ini :

"...bentuknya adalah melalui website ya...semua produk sosialisasinya harus lewat website...data kita publikasi lewat situ...kemudian yang cetak ya melalui cetakan, melalui elektronik dan non elektronik...semua ada di bank data dan masyarakat bisa mengunduhnya secara bebas..."

Hasil evaluasi terhadap penggunaan informasi SIK di Provinsi Jawa Tengah secara umum adalah "adekuat" (72,4\%). Masih ada beberapa hal yang tidak adekuat, diantaranya adalah penggunaan informasi SIK untuk mengatur alokasi sumber daya dalam proses penyusunan anggaran tahunan dan penggunaan informasi SIK dalam advokasi untuk keadilan dan peningkatan sumber daya bagi kelompok masyarakat yang kurang mampu.

Penggunaan informasi kesehatan untuk perencanaan anggaran oleh lintas program dan lintas sektor di Dinas Kesehatan Provinsi Jawa Tengah dinilai sudah memadai meskipun belum pernah dilakukan kajian khusus untuk menghitung seberapa besar penggunaan informasi SIK bagi penurunan kejadian kesakitan maupun kematian, seperti yang disampaikan oleh Kepala Seksi Mibangkes berikut ini :

...kami belum ada kajian secara khusus untuk menilai bagaimana pemanfaatan data dan berapa besar anggaran yang berdasarkan evidence base tersebut mempunyai daya ungkit terhadap penurunan kesakitan dan kematian... 
Penggunaan informasi SIK lebih sering digunakan untuk manajemen pelayanan kesehatan, monitoring dan evaluasi program kesehatan..

Berdasarkan evaluasi SIK yang telah dilakukan maka diketahui bahwa dari tujuh komponen SIK yang perlu mendapat perhatian adalah pada komponen yang masuk dalam kategori "ada tapi tidak adekuat" yaitu komponen Pengelolaan SIK, Sumber Daya SIK, Sumber Data SIK dan Manajemen Data SIK. Berdasarkan masukan beberapa partisipan dalam FGD dapat ditarik suatu kesimpulan bahwa lemahnya regulasi SIK di daerah mengakibatkan posisi pengelola SIK kurang diakui, sehingga ada kesulitan dalam mengusulkan SDM yang sesuai kompetensi SIK dan rendahnya pendanaan SIK di beberapa kabupaten/kota. Rendahnya kualitas dan kuantitas SDM SIK dan pendanaan SIK mengakibatkan komponen manajemen data SIK tidak memadai pelaksanaannya.

Rekomendasi yang dapat dirumuskan untuk SIK di Provinsi Jawa Tengah dalam rangka Penguatan SIKNAS, sebagai berikut :

/ , Pembuatan standar tata kelola SIK berdasarkan PP no 46/2014 sebagai bahan acuan untuk pengelolaan SIK di DKK dan Provinsi Jawa Tengah.

0, Membuat Perencanaan SIK dengan menyusun rencana strategis jangka pendek, menengah dan panjang.

1, Pelatihan peningkatan kapasitas petugas SIK di Provinsi Jawa Tengah yang lebih terencana berdasarkan hasil kajian tentang tingkat kompetensi petugas SIK di Provinsi Jawa Tengah.

2, Pertemuan di tingkat provinsi untuk perencanaan anggaran SIK di Provinsi Jawa Tengah untuk pembuatan menu-menu kegiatan SIK yang bisa dijadikan acuan DKK dalam mengusulkan anggaran SIK di daerahnya masing-masing.

3, Sosialisasi pemanfaatan bank data di lingkungan Dinas Kesehatan Provinsi Jawa Tengah terus dilakukan.

\section{Kesimpulan}

/, Modifikasi HMN Assessment Tools version 4.0 menjadi perangkat Evaluasi SIK Provinsi dilakukan pada item pertanyaan dengan cara menghapus item pertanyaan yang tidak sesuai dengan kondisi SIK di provinsi dan menambahkan item pertanyaan berdasarkan pada PP no 46 Tahun 2014 tentang SIK.

0, Hasil evaluasi terhadap 7 komponen SIK di Provinsi Jawa Tengah menunjukkan bahwa empat komponen berada dalam kategori "Ada tapi tidak Adekuat" yaitu komponen Pengelolaan SIK, Sumber Daya SIK, Sumber Data SIK dan Manajemen Data SIK. Sementara tiga komponen lainnya berada dalam kategori "Adekuat", yaitu komponen Indikator SIK, Produk Informasi SIK dan Diseminasi dan Penggunaan Informasi.

\section{Daftar Pustaka}

1. Kementerian Kesehatan RI. Pedoman Sistem Informasi Kesehatan. Jakarta: 2011.

2. Nyamtema, AS. Bridging the gaps in the Health Management Information System in the Context of a Changing Health Sector. BMC Med Inform Decis Mak. 2010 Jan;10;36.

3. Peraturan Pemerintah Republik Indonesia Nomor 46 Tahun 2014 Tentang Sistem Informasi Kesehatan. Jakarta: 2014.

4. Kementerian Kesehatan RI. Keputusan Menteri Kesehatan Republik Indonesia Nomor 192/MENKES/SK/VI/2012 tentang Roadmap Rencana Aksi Penguatan Sistem Informasi Kesehatan. Jakarta: 2012.

5. Departemen Kesehatan RI. Kebijakan dan Strategi Pengembangan Sistem Informasi Kesehatan Nasional (SIKNAS) : Keputusan Menkes No: 511/MENKES/SK/V/2002. Jakarta: 2007.

6. Peraturan Pemerintah Republik Indonesia Nomor 38 Tahun 2007 Tentang Pembagian Urusan Pemerintahan antara Pemerintah, Pemerintahan Daerah Provinsi, dan Pemerintahan Daerah Kabupaten/Kota. Jakarta: 2007. 
7. Odhiambo-Otieno, GW. Evaluation of Existing District Health Management Information Systems a Case Study of the District Health Systems in Kenya. Int J Med Inform. 2005 Sep;74(9):733-744.

8. Hotchkiss DR, Aqil A, Lippeveld T, Mukooyo E. Evaluation of the Performance of Routine Information System Management (PRISM) Framework: Evidence from Uganda. BMC Health Serv Res. 2010 Jan;10;188.

9. Hartono B, Bambang S, Tjahjoso D. Indonesia Health Information System Review and Assessment. 2007.

10. Utami AD, Lazuardi L. Evaluasi Kinerja Sistem Informasi Kesehatan di Provinsi Kepulauan Bangka Belitung. Universitas Gadjah Mada: 2013.

11. Budi DK, Lazuardi L. Analisis Sumber Daya Sistem Informasi Kesehatan Kabupaten Ketapang dengan Pendekatan Kerangka Health Metrics Network. Universitas Gadjah Mada: 2010.

12. Garrib A, Stoops N, McKenzie A, Dlamini L, Govender T, Rohde J, et al. An Evaluation of the District Health Information System in Rural South Africa. S Afr Med J. 2008 Jul;98(7):549-552.

13. WHO (World Health Organization). Framework and Standards for Country Health Information Systems. World Health. 2008; 2nd Edition(June); 72.

14. WHO HMN. Assessing the National Health Information System An Assessment Tool. 2008. 